\title{
Tulip In The Culture Of Uzbek People
}

\section{ARTICLE DOI:- $\underline{\text { https://doi.org/10.37547/tajssei/Volume02Issue04-05 }}$}

\author{
Adhamjon Ashirov \\ Doctor Of Historical Sciences, Professor, \\ The Institute Of History The Academy Of Sciences Of The Republic Of Uzbekistan \\ Tashkent. Uzbekistan
}

\begin{abstract}
:-
On the basis of ethnographic materials this article examines the worldview of Uzbeks living in Central Asia and the role of the tulip plant in everyday life of the Uzbeks. The author analyzes the history, genesis and local features of the spring holidays "Lola Sayli" (Tulip Festivity) and "Boychechak Sayli"(Snowdrop Festivity) that are held in Uzbekistan and Tajikistan. Also, new scientific views on the image of the tulip and its symbolic meanings in the popular folk art of the region, especially in the national suzannas, were expressed.
\end{abstract}

Keywords: Flower Festivity, Snowdrop Festivity, Tulip Festivity, Uzbeks, Culture, Ceremonies, Cult of Nature, Arts, Suzana, National Symbols

INTRODUCTION. The human is an inseparable part of nature and it has always in contact with nature and the world of plants. The ancient ancestors of the Uzbek nation have been honoring many types of the plant as the symbol of beauty, friendship, and love. Based on the connection between human and nature civilizations, cultures and ceremonies unique to different nations and regions have been formed together with mythological, religious and world views.

In the formation and development of the ancient centers of human civilization, the relationship between humans and nature has played an important role. Later, based on the experiences, methods and phenological observations of the civil society for long centuries the seasonal (spring, summer, autumn, and winter) ceremonies connected with nature have been formed. 


\section{THE IMAGE OF "TULIP” IN THE SYSTEM OF THE OUTLOOK OF THE UZBEK PEOPLE. It is known from}

history that in the territory of Uzbekistan different festivities have been held in the occasion of the awakening of nature, the beginning of the blossoming of different plants on the mountains and foothills in a particular phenological calendar. The traditions connected with the seasons of the year were a wonderful miracle of the people's thinking. Undoubtedly, like other nations, the rules, prayers, sayings, and symbols were created by the ancestors of Uzbek people too by following the changes in nature.

Flower festivals had a special place in the spring ceremonies. Most parts of the flower festivals held in the territory of Uzbekistan are connected with the type of plants that begin their vegetation in the early spring.

These plants are, mainly, connected with tulip (Tulipa L.), snowdrop (Gagea Salisb.) boygalcha (Corydalis DC.) and other local types of flora, they are honored as the first messengers of the spring and the signs that the cold days of the winter have gone away and the worm days have arrived. While in the foothill and mountainous areas of Uzbekistan the ceremonies such as "Messenger of snowdrop", "Navruz flower festival", "Tulip festival" were held, among the local people in the desert zones "Red flower", "Guli surkh", "Guli arvugon" festivals became traditional ${ }^{1}$. In particular, in Khorezm and Bukhara "Red flower Festival", in Fergana valley and around Tashkent "Tulip Festival" in some mountainous regions, especially in Chust district of namangan region and Denov district of Surkhandarya region "Hyacinth Festival" and in another regions "Snowdrop Festivals" were organized". Moreover, in Nurota foothills when the ornamental plants blossom "Red flower Festival", in Fergana valley "Tulip Festival", in Samarkand when the fruit trees, particularly, quince (Cydonia oblonga L.) blossom, "Quince Blossom Festival", in Zarafshan valley "Song of snowdrop blossom", in Bukhara when

\footnotetext{
${ }^{1}$ See: Jo'raev M. Navruz holiday. - Tashkent: Fan, 2009. - pp. 81-103; The same author: "Red flower" interpretation in modern folk art / "Boysun spring" open folklore festival. Proceedings of the International Scientific Conference "Problems of preservation of traditional folk culture." - Boysun, 2003. - P. 56; Sultanmurod Olim. Our holidays. Tashkent: Manaviyat, 2008. - pp. 35-36; Ashirov A. Ancient beliefs and ceremonies of the Uzbek people. Tashkent: Publishing House of the National Library of Uzbekistan named after Alisher Navoi, 2007. - P. 202; Lobacheva I.P. Formation of a new ritual of Uzbeks. - M .., 1975 .- P. 121; Karmysheva B. Kh. Essays on the ethnic history of the population of the southern regions of Tajikistan and Uzbekistan. - M .: Nauka, 1976 .- P. 150.

${ }^{2}$ Qoraboev U. Holidays of the Uzbek people. - Tashkent: Sharq, 2002. - P. 85.
} 
the trees in the gardens blossom and the nightingales sing "Gulgardoni Bulbulkhon" (the song of the nightingale) and many other holidays and festivals were organized ${ }^{3}$.

SNOWDROP FESTIVAL. The most ancient and widespread flower festival which has been held in Central Asia is the "Snowdrop Festival". In different regions of Uzbekistan the types of plants with the name of "snowdrop", belonging to several types blossoming from the beginning of March to April, have been defined. The types of tulip are likely to be included in them too.

The snowdrop was the messenger of the spring, therefore the people of the East considered the blossom of this plant to be the sign of the spring and was celebrated as a special festival. If we consider gathering bunches of flowers of the spring messengers in the festival which became traditional among the local people, the types of tulip (Tulipa L.) can be said to be included in them. Because, usually, the types of Gagea Salisb generally named "snowdrop" are the plants with a height of about 5-10 sm and with small (about 3-5-7 $\mathrm{mm}$ ) yellow flowers.

In the 20s of the XX century in Zarafshan valley "Snowdrop Festival" was held in the form of half-game with the participation of children. Usually, boys went to the foothills in teams to gather snowdrops. Making small bunches of flowers, they congratulated the people of the village on the spring holiday by entering the houses and singing the song "Snowdrop". They tried to give a bunch of snowdrops to the elderly people first. Because this type of flower was valuable to them, it indicated that they had seen the winter off healthy and wealthy and the spring had come and the new life had begun again. Therefore, the elderly people wiped the snowdrop against their eyelids out of respect and wished good intentions by saying "Peace be upon us, let us never see evil, let us live in peace by these days of the next year" and gave them bread or dried fruits as a gift" 4 .

Most of the scholars, who studied the ceremonies of Central Asian people held when snowdrop blossomed, write that the messengers of the snowdrop were ten-year-old boys, they sang a special song about the snowdrop and shared the spring mood of happiness with the people ${ }^{5}$. In the mountainous areas of Tajikistan not only little children, but also students of madrasahs delivered the

\footnotetext{
${ }^{3}$ Tultseva L. A. Modern holidays and ceremonies of peoples. - M .: Nauka, 1985. - pp. 107-108.

${ }^{4}$ Sukhareva O. A. Festivals of flowers in the plain Tajiks (late XIX - early XX century) / Ancient rites, beliefs and cults of the peoples of Central Asia. - M .: Nauka, 1986. - P. 31-32.

${ }^{5}$ See: Jo'raev M. Uzbek seasonal ceremonial folklore. - Toshkent: Fan, 2008. - pp. 85-90.
} 


\section{American Journal of Social Science and Education Innovations}

\section{[Volume-II IssuelV][Pages = VI-XVI] [2020]}

\section{Website: http://usajournalshub.com/index.php/tajssei/ＩSSN (e): 2689-100X}

message of the snowdrop 6 . It is seen that the first messengers about the snowdrops were young boys, they longed for the first awakening time and happiness in nature. Meanwhile, this process was accepted as one form of the connection between the awakening of nature and childhood.

One of the ceremonies related to flower festivals is "Navruzgul Festival", the philologist scholar M.Juraev gives the following information about this festival: "at the beginning of the XX century it was held every spring in Sijjak village of Tashkent region".

When navruzguli grew up, the Sijjakians used to go out mountains and fields to celebrate navruz. In this festival boys and girls enjoyed themselves and sang songs. Women, young girls, and daughter-inlaws gathered red, yellow, brindled tulips and bogalchas (Corydalis ledebouriana Kar. \& Kir) from the fields and wore on their hair and ears. The ancestors believed that the flowers worn on the hair and forehead would magically affect the people to have many children?

"TULIP FESTIVAL". One of the ancient and most widespread public festivals connected with the decorative plants growing in natural conditions is the Tulip festival. As it is stated above, the "Tulip festival" was mainly held in the mountainous areas of Fergana valley, Tashkent, Samarkand, and Surkhandarya were tulips and wild poppies grow and blossom (Papaver pavoninum C. A. Mey., Roemeria refracta DC.). This festival was organized and ruled by the appointed people "Lolachilar".

Going out for the traditional "Tulip festival" has an important practical significance in bringing up the emotion of love for the nature of people among the Uzbek nation, so it was celebrated particularly as a solemn. Whereas, celebrating the time when the tulips blossom existed in different countries of the world too.

According to the information of the ethnographer Ye.M.Pesherova, in the 20s of the XX century in Isfara village of Kokand uezd "Tulip festival" was held in a particular way, usually, between 10-20 days of April. According to the tradition, the celebration day of the "Tulip festival" was appointed firstly by the respected people of the village and a comfortable tulip field was chosen as the celebration place. After that, a bushy willow (Salix ssp.) was cut and cleaned from the leaves and was decorated with the tulips gathered from the field. They set the bush of the tree decorated with flowers in the middle of

\footnotetext{
${ }^{6}$ Sukhareva O. A. Festivities of flowers in the Tajik plains .... - P. 32.

${ }^{7}$ Jo'raev M. Uzbek seasonal ceremonial folklore. - Toshkent: Fan, 2008. - P.135
} 


\section{American Journal of Social Science and Education Innovations}

\section{[Volume-II IssuelV][Pages = VI-XVI] [2020]}

\section{Website: http://usajournalshub.com/index.php/tajssei/_ ISSN (e): 2689-100X}

the tulip field. Then the "Tulip Festival" began and during the festival, songs were sung and young people danced and enjoyed themselves.

The considerable point is that all people in the village could participate in the festival. The first day of the festival lasted until the evening and in the end, the decorated bush of the tree was taken to the village and was put in the corner of the market. The next day of the festival men and women from Isfara visited graveyards in teams, the women went to Khuja Abdulloi surkhi, that's the graveyard of the saint "Kizil Abdulla" and the men went to the graveyard of Khuja Abdulloi Kabut-Push".

As O.A.Sukhareva noted, the word "surkhi" (the epithet "Red") in the name of the graveyard "Khuja Abdulloi surkhi" shows that the graveyard is connected with the holiday of "Red flower" and the women's swimming in the river during the visitation shows a religious character ${ }^{9}$.

In Parkent, the foothill area of Tashkent "Tulip festival", with the participation of girls, was held too. The girls of the village went up to the highland on the bank of the Parkent canal when the flowers opened and held the "Tulip festival" picnic. The participants from the neighboring villages joined the festival (picnic) and they played the doira (drum), sang songs and danced, performed lapars and ulans (songs sung by women and men together turn by turn in gatherings).

Most of the participant girls wore beautiful red dresses for the picnic. During the picnic (festival) boys took off their sashes and wrapped sweets and bread and sent them to the girls they liked by little children. Due to "Tulip festival" many boys and girls introduced with each other and gave tulips and sometimes this procedure ended with the ceremony of match-making ${ }^{10}$.

In M.C.Andrev's opinion, at the beginning of the XX century there was a thought among the population of Mozori Sharif city of Afganistan that the poppy was the blood of imam Khusein killed in Karbolo. Ye.M. Peshereva noted that tulip was connected with the ancient dying and reviving cult of the nature ${ }^{11}$. U.Jakhonov and other researchers also noted that such kind of festival and picnics were held

\footnotetext{
${ }^{8}$ Pesherova E. M. Tulip Festival .... - pp. 354-355.

${ }^{9}$ Sukhareva O. A. Festivities of flowers in the Tajik plains .... - P. 32.

${ }^{10}$ Sukhareva O. A. Festivities of flowers in the Tajik plains .... - P. 33.

${ }^{11}$ Sukhareva O. A. Festivities of flowers in the Tajik plains ......-P.41.
} 


\section{American Journal of Social Science and Education Innovations}

\section{[Volume-II IssuelV][Pages = VI-XVI] [2020]}

\section{Website: http://usajournalshub.com/index.php/tajssei/ ISSN (e): 2689-100X}

in Sukh district of Fergana valley, in Khorezm, Bukhara and Samarkand regions as well ${ }^{12}$. But, no detail information was noted about the order and form of their celebration.

The study of "Tulip festival" shows that visiting the shrines and graveyards is the part of these festivals, in our opening the reasons must be: firstly, usually, it was held at the places where tulips grew and opened. There were such places around the sacred shrines and graveyards; secondly, remembering the dead was the ancient tradition for the East people, especially, for the Uzbek people; thirdly, the most interesting is that the red color of tulips and poppies was compared to the human blood. There was a thought among the people that the red flowers take their red color from the blood of the ancestors. According to the legends told by the informers during the ethnographic field researches, "the earth sucks the blood of the dead and the tulips and poppies take their red color from it and gives them the second life and decorate the land with the beautiful dresses - spring flowers". Also, in Isfara the graveyard where the women went to swim was called Abdulli Surkh (red) and in Boysun the graveyard where the red flower picnic was held was called Guli Surkh (Red flower).

Thus, the ethnographic materials collected in isfara, Samarkand, and Parkent indicate that the "Tulip festival" did the same ceremonial function in all the regions. Furthermore, the red tulip in the festival must have been considered to be the symbol of the awakening of nature with the arrival of the spring and the beliefs of the ancestors as well.

\section{THE DESCRIPTION OF THE TULIP IN THE FOLK ART CULTURE.}

In the folk art culture embroidering, that is suzanas (a type of wall hanging) are distinct for their uniqueness. It is known, there are many embroidering centers in our Republic that they are differentiated from each other by the types, colors, designs, styles, and sizes of their products. In particular, in Nurota, Samarkand and Tashkent pressed seam; in Shahrisabz and Kitab kandahayol and iroki; and in Bukhara yo'rma seams are widely used. But, some similarities can be seen in some other objects. Particularly, the embroidery articles such as suzana, zardevor (a type of embroidered wall hanging), prayer rug, bed sheet, sash are knitted almost in all the provinces. The article such as a mirror bag, tea bag, the salt bag can be met only in the Surkhandarya region.

\footnotetext{
${ }^{12}$ Dzhakhonov U. Agriculture of the Tajiks ... - pp. 107-108; Khamraev A. Kh. The holiday of the red ... - pp. 2126; Sukhareva O. A. Islam in Uzbekistan ... - P. 35; Snesarev G. P. Relics of pre-Muslim ... - pp. 210-214; Lisitsina G. N. Formation and development of irrigated agriculture in southern Turkmenistan. - M., 1978. - pp. 120-122.
} 
Plant-like designs, that are "Islimiy(plant-like) flowers" are widespread among the different ornaments of suzanas and wall hangings which are the inseparable part of folk embroidery. Plant-like flowers were in a form that can be joined from two sides. The ornaments performing the images of plants were a priority in all the embroidery schools of Uzbekistan (except for Tashkent school). In these ornaments tulip, cotton flower, pinks, sunflower, bindweed, iris, rose, daffodil, and other flowers were repeated.

It is not accidental that the plant-like ornaments be a priority at the national embroidery schools: the world of nature, plants, flowers, and fruits - there has been a basic circle which folk masters have always addressed to for creating new forms. Besides, the ancient public festivals related to the cult of nature and different flowers influenced the ornaments related to plant-flowers to be a priority in embroidery. The appearance of flowers in nature in spring was the symbol of the next step of cultivating the land ${ }^{13}$. Therefore the design of a flower on the embroideries prepared for weddings might have been the symbol of having the wedding party successful. Later, after Islam religion came into the country, the plant-flower ornaments were harmonized with the theme of the gardens of the Heaven and improved ${ }^{14}$.

On the suzanas of different styles and forms there were chains of favorite decorative motives joined together, its inner part was full of different forms and colors, its surroundings were decorated with the ornaments of flower leaves. This ornament was named by different names according to this inner and outer decorations and the imaginations existed in different regions. Particularly, in Nurota it was called the moon, in Bukhara, it was called the sun, and in Samarkand, it was called tulip flower. The round chains famous for its name "tulip flower" were widespread motives on the Samarkand suzanas ${ }^{15}$.

In general, the worldview based on the symbols of nature, happiness, and love is embodied in the artistic performance of the different ornaments and designs on the embroideries ${ }^{16}$.

The suzanas sewed in Boysun district of the Surkhandarya region are separate by their not only sewing technologies but also by the images as well. Particularly, one of the widespread suzanas in the region

\footnotetext{
${ }^{13}$ Sukhareva O. A. Festivals of flowers in the plain Tajiks ... - P. 31.

${ }^{14}$ Gyul E. Gardens of Heaven and Gardens of the Earth. Embroidery of Uzbekistan is the hidden meaning of sacred texts. - Moscow: Mardzhani Foundation, 2013 .- P. 73.

${ }^{15}$ Gyul E. Gardens of Heaven and Gardens of the Earth .......... -P. 75.

${ }^{16}$ Khakimov A., Gul E. Baysun. Atlas of arts and crafts. - Tashkent, 2006 .- P. 109.
} 
consisted of several round chains, the big circles in the center was the metaphorical symbols of the sun and the moon. There are one to eight such astral signs on the suzanas. The local people interpret such signs as "moon". But, in its turn, it is divided into the big and small moon. Around the planets, the symbols of different plants such as almond flower (Amygdalys ssp.) and tulip (Tulipa ssp.) are represented. Sometimes the bushes of trees are represented, a swallow or a nightingale are represented on the bushes. Thus, the composition of the suzanas was the production of the creative metaphor of heaven in the imagination of the folk masters ${ }^{17}$.

The image of tulip flowers represented on the Uzbek national suzana and other wall hangings, the stalks growing flowers were connected with the unique local semantic imaginations. Also, suzanas were hung on the walls of the room of new couples intending good wishes. Besides, the embroidered bags of the Kungirat people of Surkhan oasis were designed with the ornaments of plants awakening the emotions of peace and amity ${ }^{18}$. In Shakhrisabs embroideries the harmony of blue, yellow and red colors, the process of awakening if nature were represented ${ }^{19}$, in Surkhan embroideries gulikhaftrang (rainbow-like color consisting of seven colors), iris, cock's comb, a bunch of flowers were represented. ${ }^{20}$.

The prayer rugs knitted in Boyun were distinguished by their peculiarities. On prayer rugs, in most cases, the figure of a geometric niche indicates the direction of Kaa'ba. Outside the niche, on the prayer rugs, different plant-like designs such as the fruit of pomegranate and tulip are represented. Also, white and black almond-like images are sometimes knitted.

In general, there are different types of designs on the embroideries, they are called individually. For example, tulip, pinks, iris, rose and cock's comb and others. According to the structure, the flowers (designs) are divided into simple and complex ones: complex flowers include sunflower, multi-leaved flower, and the simple flowers include tulip, moonflower, pea-nut flower, and others. Because the flowers have different structures, they also have different names.

Thus, the tulip has a particular place in the culture of Uzbek people. By this plant, local people perform their attitude towards nature, their ecological culture and the connection between humans and

\footnotetext{
${ }^{17}$ Khakimov A., Gul E. Baysun. Atlas of artistic crafts .... - P. 109..

${ }^{18}$ Nosirova Z. Spring fragrance in Boysun patterns ... - P. 8.

${ }^{19}$ Gyul E. Color in Uzbekistan's artistic textiles // Art. - 2008. - №3-4. - P. 23..

${ }^{20}$ Nosirova Z. Spring fragrance in Boysun patterns ... - P. 8.
} 


\section{American Journal of Social Science and Education Innovations}

\section{[Volume-II IssuelV][Pages = VI-XVI] [2020]}

\section{Website: http://usajournalshub.com/index.php/tajssei/ＩSSN (e): 2689-100X}

nature. Furthermore, the tulip is widespread among the Uzbek people not only as of the form of culture but also as the anthroponyms and toponyms of different regions. Particularly, among the Uzbek names, especially, in women's names Lola, Gullola, Shalola, Lolagul, Lolajon, Lolakizgaldok are widespread. Moreover, in different places of Uzbekistan, the place names related to the toponym of tulip are widespread. Particularly, Lola district (Namangan city), Lola village (Bukhara region, Romiton district), Lola neighborhood (Chirchik city), Lolakul (Sirdarya region), Lolazor (Andijan region, Pakhtaobod district, Fergana city), Lolabulok village (Kashkadarya region, Chirokchi district), Lolazorbuvi neighborhood (Fergana region, Dangara district, Kuduk village), Lola street (Namangan, Samarkand and Chirchik cities), Lola arik (Tashkent region, Piskent district), Shalola (Fergana region Oltiarik district, Tashkent region Mirzo Ulugbek district, Tashkent region Kibray and Chinaz districts) and one of the mountain streams on the highlands of Sukok village (Tashkent region Bustonlik district) is called "Lolazor".

Undoubtedly, the connection of these toponyms with the name "Lola" is firstly the respect of the Uzbek people to this type of plant, on another side, these names indicate to us that public tulip festivals have been held here whenever.

Thus, the above material indicates that tulip is a type of plant which has taken an unrepeated place in the history, culture, practical art and ceremonial life of Uzbek people. Also, a wide celebration of the "Tulip Festival" in spring is an example of the public phenological calendar and ecological culture as well as the relationship between nature and humans.

This suzana is distinguished by a very realistic interpretation of floral motives in which steppe tulips are easily recognized. The nature of the decoration indicates that the embroidery was created by the women of semi-nomadic groups, moving to a settled way of life and adopting the tradition of making large-size embroideries. Such embroideries are attributed abroad as "Shakhrisabz, Lokai", but the Lokai did not live in the district of this city. Suzana was probably created by the Kungrat craftsmen. The motive of tulip was extremely popular in the art of the steppe inhabitants as a symbol of the spring, awakening of nature, the beginning of the new year.

Round rosace of later Samarkand embroideries are interpreted as a tulip, and a guard ring "sprouted" with leaves are variously interpreted, due to oblivion of old meanings. In this case, it is interpreted as scalloped tendrils around the rosace and is called "Small vasa" - puppies. It is believed that in the 


\section{American Journal of Social Science and Education Innovations}

\section{[Volume-II IssuelV][Pages = VI-XVI] [2020]}

\section{Website: http://usajournalshub.com/index.php/tajssei/_ ISSN (e): 2689-100X}

center of this association there are puppy heads, which, however, are more like curls of tails - the sacred meanings give way to daily interpretations

Baysun embroidery - suzanas with round rosaces (Moon) are the most widespread types among settled-farming parts of the population, which are simultaneously interpreted as tulip, poppy or a flower in general. The equivalence and interconnection of the folk ritual consciousness with the ancient signs of cosmogony and images of the cult of nature is manifested in this duality of meanings: the rosaces were simultaneously associated with both the archaic astral cult and the cult of nature, which found reflection in the celebration of Navruz and the appearance of the first spring flowers (guli surh).

\section{References}

1.

Ashirov A. Ancient beliefs and ceremonies of the Uzbek people. - Tashkent: Publishing House of the National Library of Uzbekistan named after Alisher Navoi, 2007.

2.

Gyul E. Color in Uzbekistan's artistic textiles // Art. - 2008. - №3-4.

3.

Gyul E. Gardens of Heaven and Gardens of the Earth. Embroidery of Uzbekistan is the hidden meaning of sacred texts. - Moscow: Mardzhani Foundation, 2013.

4. Jakhonov, Usto. Agriculture of Tajiks in the Sokh Valley in the late XIX - early XX centuries.

: (East.-Ethnographic research.) / Usto Jakhonov; Repl. ed. A. K. Pisarchik; Academy of Sciences of the Tajik SSR, Institute of History A. Donisha. - Dushanbe: Donish, 1989 .- 216 p. : ill .; 20 cm

5. Jo'raev M. Navruz holiday. - Tashkent: Fan, 2009.

6. Jo'raev M. "Red flower" interpretation in modern folk art / "Boysun spring" open folklore festival. Proceedings of the International Scientific Conference "Problems of preservation of traditional folk culture." - Boysun, 2003.

7. Jo'raev M. Uzbek seasonal ceremonial folklore. - Toshkent: Fan, 2008.

8. Khakimov A., Gul E. Baysun. Atlas of arts and crafts. - Tashkent, 2006.

9. Lisitsina G. N. Formation and development of irrigated agriculture in southern

Turkmenistan. - M., 1978.

10. Lobacheva I.P. Formation of a new ritual of Uzbeks. - M .., 1975 . 
11. Karmysheva B. Kh. Essays on the ethnic history of the population of the southern regions of Tajikistan and Uzbekistan. - M .: Nauka, 1976.

12. Khamraev A. Kh., Holiday of the Red Rose, - Izvestia AN UzSSR, Series of Social Sciences, 1958, No. 6

13. Nosirova Z. Spring ifori in Boysun patterns // Echo from Maziy. 2008. №1.

14. Pesherova E.M."Tulip Festival (Lola) in the village of Isfara, Kokand County" / V.V. Barthold. Publication of the Society for the Study of Tajikistan and Iranian Nationalities Beyond. Tashkent. 1927.

15. Sukhareva O. A. Festivals of flowers in the plain Tajiks (late XIX - early XX century) / Ancient rites, beliefs and cults of the peoples of Central Asia. - M .: Nauka, 1986.

16. Sukhareva O. A., Islam in Uzbekistan, Tashkent, 1960, p. 35;

17. Snesarev G.P. Relics of pre-Islamic beliefs and practices in Khorezm Uzbeks. M.: Science, 1969. -369 p.

18. Sultanmurod Olim. Our holidays. - Tashkent: Manaviyat, 2008.

19. Qoraboev U. Holidays of the Uzbek people. - Tashkent: Sharq, 2002.

20. Tultseva L. A. Modern holidays and ceremonies of peoples. - M .: Nauka, 1985. 